\title{
Correction to: the Twofold Task of Union
}

\author{
Alexander Jech ${ }^{1}$ \\ Published online: 16 November 2019 \\ (C) Springer Nature B.V. 2019
}

\section{Correction to: Ethical Theory and Moral Practice (2014) 17:987-1000. https://doi.org/10.1007/s10677-014-9502-3}

The original version of this article unfortunately contained an error. In footnote 1, the "[My 2013]" and "[My other 2013]" should be updated.

The footnote should be read as:

This idea of love as involving persistent concern with someone or something over time is developed in both "Affinity and Reason to Love" (American Catholic Philosophical Quarterly 87:1 (2013): 117-136) and "To Will One Thing" (American Philosophical Quarterly 50:2 (2013): 153-165) and owes something to Harry Frankfurt's work on both care and love. See Frankfurt's The Reasons of Love (Princeton, NJ: Princeton University Press, 2004) for a representative example of his view.

Publisher's Note Springer Nature remains neutral with regard to jurisdictional claims in published maps and institutional affiliations.

The online version of the original article can be found at https://doi.org/10.1007/s10677-014-9502-3

Alexander Jech

awjjech@gmail.com

1 Department of Philosophy, University of North Carolina at Chapel Hill, Chapel Hill, NC, USA 